\title{
Contribution of Cooperation and Specialization for Technological Development and Associated Social Change
}

\author{
Slavena Stoyanova \\ Konstantin Preslavsky University of Shumen 115, Universitetska str., Shumen, Bulgaria
}

\begin{abstract}
Established on the basis of certain principles and values, with their democratic structure, cooperatives contribute to socio-economic development, provide employment and contribute to meeting the needs of their members and clients.

In its written statutes, the Rochdale cooperatives, considered the first, set the following socio-economic goals, valid today: co-construction of homes, production of consumer goods, purchase of land to secure employment for unemployed members and others. The stated objectives clearly distinguish the activities carried out by the cooperatives. The basis for this distinction is the ability to specialize in one or another area of the economy. Through cooperation and specialization technological development is achieved.
\end{abstract}

Keywords - cooperation, specialization, technological development.

\section{Introduction}

Human labor, including its cooperative form, is based on a combination of general and specific laws of social development and, above all, of economic ones. The attitude towards cooperation requires the use and application of universal values such as freedom, humanism, equality, justice and tolerance. The driving forces of economic and social progress, as well as the specificity of the current mode of production, have an impact.

DOI: $10.18421 /$ TEM93-26

https://doi.org/10.18421/TEM93-26

Corresponding author: Slavena Stoyanova, Shumen University, Shumen, Bulgaria.

Email: slavena.stoyanova@shu.bg

Received: 02 Jun 2020.

Revised: 14 July 2020.

Accepted: 24 July 2020.

Published: 28 August 2020.

(cc)BY-NC-ND@ 2020 Slavena Stoyanova; published by UIKTEN. This work is licensed under the Creative Commons Attribution-NonCommercial-NoDerivs 4.0 License.

The article is published with Open Access at www.temjournal.com
As a social organization, the cooperative brings together a certain part of society on the basis of [12]:

- need - the cooperative is created by people who need such an organization, such as the cooperative organization; created by people through participation in the founding of a cooperative or subsequent desire to become a member, the cooperative emerges as a community of cooperators - a cooperative community;

- statutory activity - the cooperative operates on the basis of a statute;

- goals - the goals of the cooperation derive from the material interests of the weak and middle classes of society; the cooperative pursues an activity for their satisfaction and the purpose of the cooperative is economic, not political;

- mission - ability to unite the weak economic layers, the poor and the middle class, in which the cooperative has the mission to bring them into the market economy and adapt them to it, by which its operation would guarantee their existence in a very complex, diverse and highly competitive economic environment;

- lack of restrictions, apart from legal ones, for membership in the cooperative - the cooperative has an attractive force and includes in its community of members people without distinction of gender, religion, race and others.

Today, cooperatives are an important factor in the economic development and prosperity of many economies. Cooperation is a possible option for solving many acute economic and social problems. It is a socio-economic phenomenon that demonstrates a person's desire for cooperation, mutual assistance and equality in the main spheres of public life. By joining together and cooperating with each other, individual small producers have the opportunity to preserve, develop and sell their production.

\section{Relationships Between cooperation and} Specialization

The word cooperative (derived from Latin cooperatio) literally means cooperation, mutual assistance. This definition can be derived as a definition of cooperation in the broad sense of the 
word. In the narrow sense, the word cooperative is regarded as a public-economic organization, the organization and manner of operation which are governed by certain principles [5], [7], [8]:

- Voluntary and open membership - cooperatives are voluntary organizations open to all persons who need their services and who wish to accept the responsibilities of membership, without any gender, social, racial, political or religious discrimination;

- Democratic governance of the members - the members of the cooperative themselves actively participate in the development of the cooperative's policy and plans for its implementation, participate in decision-making, and have a mechanism for monitoring their implementation; the members of the cooperative choose their own guides and the guides report to them;

- Economic participation of the members in the activity of the cooperative - they jointly own and democratically manage the capital of the cooperative, and the realized profit is used for the development and strengthening the activity and to satisfy the needs of the members - economic, industrial, social and cultural;

- Autonomy and independence of the cooperative this prevents administrative interference from the activities of cooperatives, which are autonomous aid and mutual assistance organizations managed by their members and entering into agreements with other organizations, including governmental ones, or raising capital from outside sources conditions under which democratic governance and control by members are ensured and the autonomy of cooperatives is maintained;

- Education, training and information cooperatives provide education and training to their members, their elected representatives, managers and employees (workers) so that they can effectively participate in the development of the cooperative, in addition to informing the general population - especially the young and leaders - about the nature, nature, benefits and benefits of a cooperative, because only educated, knowledgeable and well-trained people in their field can contribute to the overall development of the cooperative and its strengthening;

- Cooperation between cooperatives - the cooperation of cooperatives at local, national and international level can contribute to their strengthening and the prosperity of the cooperative system as a whole, as well as the current conditions of liberalization and economic pressure of major concerns and mergers at national and transnational level objectively require the cooperation of cooperative organizations between them, because only in this way can they assert their right to exist;

- Care for the community as a whole cooperatives work for the sustainable development of their communities through the policy defined and adopted by their members.

These principles are seen as rules that have to be strictly adhered to. They are also guiding guidelines for behavior, discipline, decision making, and restrict and prohibit certain actions. The principles should be applied in the daily work of cooperatives. They form the core of the cooperative entity and through them the cooperative is realized as such [3], [13].

The main importance of the cooperative is associated with a voluntary association of people, organization of labor and the function of capital to serve the objectives pursued [12]. By volunteering, small-scale producers join forces to increase production. The goals of the cooperatives are socioeconomic, and they are related to the joint construction of housing, production of consumer goods and purchase of land in order to provide employment for unemployed members and others. The peculiarity of the activities carried out by the cooperatives can be distinguished here, which enables their classification (classification). The basis for this distinction is the ability to specialize in one or another area of the economy. The above statement is supported by the following facts:

First: Cooperativeness is inherently economic and it is a "derivative" from the specialization of production. Production specialization is one form of organization within the production process. Specialization achieves the concentration of the activity of the organization or organizations in a given industry for the production of a limited nomenclature comprising a given type of product or technologically homogeneous production. Specialization in an activity logically leads to the creation of specialized enterprises and industries as the highest manifestation of the law on division of labor. Specialized enterprises are engaged in the preparation of individual objects, units, parts, production of parts, stages, phases of the general technological process for the preparation of a particular product. Creating the ready-to-use product requires specific interaction, teaming together in order to allow this finished product to be assembled with particular demand. In this way, cooperation develops according to the degree of development of the specialization and beyond its limits it remains irrational.

Second: Cooperation takes place in various forms, in accordance with the forms of specialization. The specialization applied as a classification feature to cooperatives can be the basis for proposing the following systematization of cooperatives: 
- Subject (industry) cooperation - companies focus their activities on the production of individual items suitable for independent use - bread, wine, butter, canned food, sugar and others. On the basis of this type of cooperation the branch affiliation of the enterprise is formed. The strict specialization in a given field leads to the improvement of the production process, but does not allow the expansion in the spheres of activity;

- Detailed (production) cooperation - companies focus their activities on the production of certain parts or components with regard to the finished product, suitable for independent use or consumption. This form of cooperation is typical for industries producing structurally complex (composite) products - mechanical engineering, instrument making, automotive industry and others;

- Technological cooperation - the activity focuses on production in one or several phases within the production process. It provides an opportunity for rational dispersal of the branches within a given type of industry, bringing some closer to the source of production and others to the consumer. This type of cooperation is developing well in industries such as mining (ore mining and processing); food industry (extraction and processing of sugar), extraction, processing and bottling of wine, grain production - activities for collection, storage, processing of grain and its subsequent processing (flour, bread, pasta and other bakery products).

Third: The process of cooperation, as well as the process of specialization, is characterized by a certain level. It is determined on the basis of indicators, the most important of which are:

- relative weight of the cooperatively made to the total cost or value of the production produced by the enterprise - ratio between the cooperatively made (in BGN) to the prime cost or total value of the production produced by the enterprise (in BGN);

- number of enterprises cooperating with each other;

- volume of production produced by cooperative (specialized) enterprises to the total volume of production in the industry;

- relative weight of the cooperated (specialized) enterprises in the total volume (number) of the enterprises in the branch;

- quantity and share of a technologically homogeneous group of products in the total volume of produced products;

- relative weight of the specialized equipment to the total volume (park) of machines.
Fourth: The economic efficiency regarding the forms of cooperation is determined by the economic efficiency of the specialization. It is much cheaper to get a cooperatively produced product, completed by self-specialized companies, than to produce each part in small quantities. Here the effect of large-scale specialized production and the effect of concentration and specialization of production are unconditionally manifested.

Fifth: Production cooperation usually manifests itself in industries that produce structurally complex products - engineering, instrumentation, automotive and others. In the food industry, a special, relatively effective form of cooperation initially appeared, based on the joint use of nearby food enterprises, the object of ancillary production and service farms with maximum full year-round load. The effect and economic expediency of this specific form of cooperation are complemented by the possibility of mitigating the seasonal nature of the activities comprising many industries, and strengthening the interconnectedness of the objectively related distribution of enterprises in the processing area of raw materials or areas of consumption.

The stated facts unequivocally direct and confirm the existence of a direct connection and dependence between specialization and cooperation. Industries are emerging in certain areas of the economy, which, focusing on specialization, will inevitably lead to the emergence of subsequent cooperation, which in turn to technological development.

\section{The Potential Contribution of the Cooperatives to the Technological Development and the Accompanying Social Changes}

As an enterprise, the activity of the cooperative is oriented to the needs, interests and aspirations of the member-cooperators. The economic activity of the cooperative is aimed at creating goods (material and spiritual) through which certain human needs are met. The cooperative carries out its activities to support, serve and assist its members in order to more effectively meet the needs and interests of their private individual farms and households. The cooperative cannot be separated from the holdings and households of the co-operative members, because its activity directly derives and depends on their participation. Therefore, the existence of the cooperative is determined by the needs and interests of its members. The economic activity carried out by the cooperative is also the basis for expanding the social base of the cooperative - its membership. The cooperative works for the people. They are their social capital. Therefore, by voluntarily associating and cooperating with each other, individual small producers have the opportunity to maintain and 
realize their production. Cooperatives are objectively necessary for survival and meaningful human existence.

As it is customary in all EU Member States and globally, cooperatives have a legal framework [4], [6]. It protects the interests of members and third parties. It regulates the establishment and economic activity of cooperatives [2], [10]. The latest trends in the field of cooperative legislation in EU countries are related to the following: respecting (strictly or freely) the cooperative principles, the cooperative legislation of the individual countries seeks to reduce the restrictions imposed by the cooperative form. Innovations have been introduced in the rules and laws governing cooperatives in many of the Community countries. The reforms concern:

- reduction of the minimum number of persons required for the establishment of the cooperative;

- the possibility to give some members more than one vote;

- expanding the boundaries of activity;

- trade with non-members of cooperative associations;

- possibility to issue specific bonds representing venture capital or debt capital;

- authorization of third parties to participate in the share capital;

- allowing the transformation of cooperatives into joint stock companies;

- opportunities to increase the use of investment cooperation options and others.

These changes aim to allow cooperatives access to financial markets and to "loosen" the restrictions and requirements for the formation of cooperatives [10]. The fact that some of these innovations are in conflict with the cooperative principles is under discussion. Taking into account the needs of the growing cooperatives in the modern economy, the innovations are considered desirable if they do not contradict the basic essence and goals of the cooperative.

Established as an association of individuals who carry out commercial activities through mutual assistance and cooperation, and has a certain legal framework, the cooperative is distinguished by its functional distinctiveness and determined by the subject of the economic activity. The subject itself is determined by the goals pursued by a business organization. In this respect, the cooperative form of economic activity shows great diversity. Cooperatives are established in almost all areas of economic life, namely:

- cooperatives in the field of education, as part of school management, which allow parents and teachers to influence the development of the education system;
- cooperation in the field of electricity supply, enabling the establishment of electrical cooperatives for the supply of electricity to cooperating members at preferential prices, following the example of "Ecopower" cvba Belgian cooperative for the use of renewable energy sources such as the so-called REScoop [1], [9];

- social cooperatives, realized mainly through labor-production cooperatives, but also independently, providing jobs for members with disabilities or for other excluded social groups, such as drug addicts, prisoners and others;

- cooperatives engaged in the care of children and adults, enabling working parents to mutually negotiate the service "child care" under their control and allowing women to participate in the labor market and directly offer paid work;

- university cooperatives providing important services for students - accommodation, goods at lower prices, consultations and others;

- cooperatives in the field of consumption, giving the opportunity to purchase goods at a discount in the store network of the cooperative, which contributes to the realization of higher turnovers;

- cooperatives of shareholders, aimed at encouraging workers to invest in their own association and to pool their voting power;

- e-commerce cooperatives, enabling small craft enterprises to offer and sell their products over the Internet, following the example of COOP China, offering the online platform "International Cooperative Pavilion", as well as the example of the CS of consumer cooperatives in Russia offering the application "Global COOP Connect" for mobile phones and personal computers;

- cooperatives in the field of healthcare, artistic and cultural circles, providing access to a wider range of specialists working in one place, as through the cooperatives of artists is given the opportunity for the realization of artists left outside the theaters;

- cooperatives of pensioners and the temporarily unemployed, with the possibility for those falling into these categories to be realized through hourly or seasonal work, achieving an increase in living status, increasing disposable income, and hence - generating and increasing total consumption of goods and services and growth of the national economy;

- realization of home production through the use of labor-production cooperatives, as in conditions of home production a number of goods could be produced for which serial production is not applicable and no investment in machinery and equipment is required, but from the benefits of combining this work of running a household 
would benefit many mothers with young children and people with disabilities;

- cooperatives in the field that includes purchase of agricultural products, which create an opportunity for effective cultivation of personal plots of land in connection with a particular type of agricultural products and its sale, significantly reducing the storage cost of manufactured products by individual producers, in low quantity of purchased products with guaranteed quality, which is a prerequisite for the realization of a good price by the cooperative-buyer;

- cooperation in the field of household services home services, construction and repair works, repair of shoes, bags, dry cleaning, such as the introduction of new technologies in these areas of manifestation of the cooperative form of economic activity, as well as expansion of existing forms would reduce the high labor costs associated with running a household;

- student and students' cooperatives, which achieve a sense of collectivism, solidarity, mutual assistance, material incentives, etc., while covering temporarily unemployed persons.

From the above it can be summarized that the cooperative business model has found its place and application in almost all areas of activity.

\section{Competitive Advantages of the Cooperative Business Model}

Resisting time, challenges and competition, the cooperative manages to preserve its goals and principles, which are a distinctive feature, different from other forms of business. As a form of economic activity based on legal regulations, the cooperative has certain advantages:

- independence from external investors due to a strong equity base; the existing external pressure leads to a more sustainable development of the enterprise;

- source of employment for persons at risk of social exclusion;

- an important source of work and management experience for many women;
- create an opportunity for realization and exercise of managerial responsibility by individuals; there is an increased motivation of employees as owners, and democratic decision-making leads to greater resilience of the latter;

- mobilize the latent local and regional potential through companies with various partners, consumers are also members of the cooperative and it has direct information about their needs, changes in behavior, habits and expectations;

- cooperative approach to business - consumers and suppliers are interested in doing business with trusted companies that are related to the social and environmental goals of their own business; organizations that demonstrate a balance between efficiency and values have a market advantage.

\section{Conclusion}

Summarizing the issues related to the ideas of origin and specific characteristics, the basis for defining the enterprise as a cooperative, we can point out that the cooperative, respectively the cooperative model and cooperation have a long history and traditions. Existing heterogeneous theories discuss the ideas and goals of cooperation. The trend in recent years is on behalf qualitative changes in the discussion of the optimal cooperative concept, in line with the new market realities.

In a changing world of work, cooperatives have to respond to new opportunities and challenges. Concepts of "platform cooperatives" [11] could lead to innovative ways of working in and with cooperatives in the 21 st century. With full recognition of the contribution including these new concepts, they (the concepts) could be successfully combined with the tools and methods of the cooperative movement, which will strengthen and concretize the contribution that cooperatives can make to address the problems associated with work and employment in a changing world of work.

The conclusion to be drawn is that cooperatives are primarily associations of natural or legal persons who are subject to principles of operation different from those to which other economic entities are subject. As a market entity operating in conditions of intensified market competition, cooperatives should organize their activities so that it responds to the changing dynamic environment.

\section{Acknowledgements}

The publication is funded by project RD-08-93 / 28.01.2020, paragraph "Scientific Research" of the University of Shumen "Bishop Konstantin Preslavski". 


\section{References}

[1]. Caramizaru, A., \& Uihlein, A. (2020). Energy Communities: An Overview of Energy and Social Innovation. JRC Science for Policy Report JRC119433.

[2]. Europe, C. (2016). The Power of Cooperation. Cooperatives Europe Key Figures 2015. Brussels: Coopera tives Europe.

[3]. Fairbairn, B. (1994). The meaning of Rochdale: The Rochdale pioneers and the co-operative principles (No. 1755-2016-141554).

[4]. Henrÿ, H. (2005). Guidelines for Cooperative Legislation. Geneva: International Labour Organization.

[5]. International Co-operative Alliance (2020). Cooperative identity, values \& principles.

Retrieved from: https://www.ica.coop/en/cooperatives/cooperativeidentity [accessed: 28 February 2020].

[6]. Luyts, S. (2017). Collaboration between local authorities and Renewable Energy Cooperatives. [Master of Science Thesis]. KTH School of Industrial Engineering and Management, Stockholm.
[7]. Oczkowski, E., Krivokapic-Skoko, B., \& Plummer, K. (2013). The meaning, importance and practice of the co-operative principles: Qualitative evidence from the Australian co-operative sector. Journal of cooperative Organization and Management, 1(2), 54-63.

[8]. Okem, A. E. (Ed.). (2016). Theoretical and Empirical Studies on Cooperatives: Lessons for Cooperatives in South Africa. Springer.

[9]. Rijpens, J., Riutort, S., \& Huybrechts, B. (2013). Report on RESCoop business models Liege: EMES network and Centre for Social Economy. University of Liege.

[10]. Şafakli, O. V. (2011). Impacts of Cyprus' European Union Accession on Turkish Cypriot Cooperatives with Emphasis on the Financial Sector of Cooperatives. Doğuş Üniversitesi Dergisi, 3(2), 111123.

[11]. Scholz, T. (2016). Platform Cooperativism: Challenging the Corporate Sharing Economy. Rosaluxemburg Stiftung, New York.

[12]. Treneva, M. (1994). History and Theory of Cooperation. University Publishing House Economy, Sofia

[13]. Zeuli , Kimberly A. , and Cropp , Robert ( 2004 ). Cooperatives: Principles and Practices in the 21st Century. Madison : University of Wisconsin Center for Cooperatives. 